Asian J. Med. Biol. Res. 2020, 6 (3), 491-498; doi: 10.3329/ajmbr.v6i3.49798

\author{
Asian Journal of \\ Medical and Biological Research \\ ISSN 2411-4472 (Print) 2412-5571 (Online) \\ www.ebupress.com/journal/ajmbr
}

\title{
Article \\ Effects of aqua drugs and chemicals on the farmed shrimp (Penaeus monodon) in southern coastal region of Bangladesh
}

\author{
Md. Asek Uddin ${ }^{1 *}$, Rashidul Hassan ${ }^{1}$, K. M. Abdul Halim², MT. Nur-A-Sharmin Aktar ${ }^{1}$, Most. Farida
} Yeasmin $^{2}$, Md. Hamidur Rahman ${ }^{1}$, Moin Uddin Ahmad ${ }^{2}$ and Gias Uddin Ahmed ${ }^{1}$

${ }^{1}$ Department of Aquaculture, Bangladesh Agricultural University, Mymensingh-2202, Bangladesh

${ }^{2}$ Department of Fisheries, Ministry of Fisheries and Livestock, Bangladesh

*Corresponding author: Md. Asek Uddin, Department of Aquaculture, Bangladesh Agricultural University, Mymensingh-2202, Bangladesh. Phone: +8801816136185; E-mail: asek48739@bau.edu.bd

Received: 21 August 2020/Accepted: 19 September 2020/ Published: 30 September 2020

\begin{abstract}
The study was conducted to observe the effects of aqua drugs and chemicals on the health of farmed shrimp (Penaeus monodon) in southern coastal region of Bangladesh. Samples were collected from shrimp farms and ghers in three upazilas of Cox's Bazar district, namely Cox's Bazar Sadar, Teknaf and Maheshkhali upazila during March 2018 to October 2018. Data were collected through personal contact, questionnaire interview and discussion with key informants. During the study period water temperature were ranged between $26^{\circ} \mathrm{C}$ to $32^{\circ} \mathrm{C}$ in summer and $23^{\circ} \mathrm{C}$ in rainy season. The highest $\mathrm{pH}$ was $8.0 \pm 0.20$ recorded from Beximco Shrimp Farm of Cox's Bazar Sadar in summer and the lowest was $7.0 \pm 0.23$ from the Aquaculture Farm Limited of Cox's Bazar Sadar. Farmers in the study areas used Geotox to remove gas, TSP to proliferate algae and Zymetin to inhibit growth of pathogens and to promote shrimp growth. The highest recovery was recorded 90-96\% by use of Bleaching powder in Aquaculture Farm limited of Cox's Bazar Sadar area. On the other hand, the lowest recovery was recorded 60-65\% by use of Zeolite plus in Beximco shrimp farm of Cox's Bazar Sadar upazila. The average recovery was recorded from Beximco shrimp farm of Cox's Bazar Sadar upazila. By use of Ecodoxin Zoothamnium was 80-85\% recovery. Farmers used more aqua-drugs in rainy season than summer. By use of Oxyflow instant oxygen supply was recorded $75-80 \%$ recovery. The highest recovery was recorded 90-95\% by use of Lime in Unique Aquaculture of Teknaf. On the other hand, the lowest recovery was recorded $60-65 \%$ by use of Renamox in MKA shrimp farm of Teknaf upazila. The average recovery was recorded Unique Aquaculture of Teknaf upazila. From field and laboratory observations it was revealed that the study area had potentiality for shrimp culture, although necessary measures need to be taken specially during rainy season.
\end{abstract}

Keywords: aqua drugs and chemicals; shrimp farm; ghers; Penaeus monodon; southern coastal region

\section{Introduction}

Bangladesh has a favorable condition for shrimp culture. This country is blessed with 36 shrimp species. Bangladesh entered the global export market for shrimp in the early 1970s. It is the fourth largest foreign income earner. Rapid expansion of shrimp culture was started in Bangladesh from the 1980s. The contribution of coastal aquaculture, particularly black tiger shrimp (Penaeus monodon) culture to both rural and national economics have become a major source of export earnings and employment in the coastal areas of Bangladesh. In fiscal year 2017-18 the country had produced 2,47213 metric tons of shrimp, exported 36,168 metric tons and earned 3527.07 crore Taka. The country exported the shrimp in USA, EU, Japan, Saudi Arabia, UAE and Gulf States (DoF, 2019).

With the expansion of aquaculture in Bangladesh, there has been an increasing trend in using chemicals in aquatic animal health management. For health management of shrimp several types of antibiotics and probiotics are used by the farmers. The antibiotics, which have been applied in aquaculture for over fifty years for treating for bacterial infection in shrimp. About 34 pharmaceutical companies supply different aqua-drugs and 
chemicals in 19 coastal district and most of the products are supplied by 10 companies. Aqua-medicines are indeed essential ingredients for successful aquaculture (Alam, 2014). Farmers are using a range of chemicals to control shrimp disease. The purpose of use chemicals and drugs is to improve growth and disease resistance capacity of fish and shrimp (Ahmed et al., 2014).

The quality and quantity of water used for shrimp culture is a critical factor affecting the sustainability of the industry. Water quality is critical in the hatchery and during the grow-out period in ponds. It is recommended that the water for shrimp culture should be free from agricultural, domestic and industrial pollution and be within the required salinity and temperature ranges (Apud et al., 1989). In any shrimp farming, management of water quality is of primary consideration particularly in ponds with higher stocking rates. Degradation of water quality is detrimental to shrimp growth and survival. Good quality water is usually defined as the fitness or suitability of the water for survival and growth of shrimp (Boyd, 1976).

Shrimp of summer season had reduced pathological changes in hepatopancreas than those of rainy season. From clinical, histological and pathological point of view healthy shrimp were noticed in summer and moderately infected in rainy season. It could be mentioned that production and health status of shrimp were increased in summer season of Cox's Bazar area compared with other areas and season (Uddin et al., 2019).

\section{Materials and Methods}

\subsection{Study area}

The study was conducted from March to October, 2018 at three different upazilas viz., Cox's Bazar Sadar, Teknaf and Maheshkhali of Cox's Bazar district to observe the effects of aqua drugs and chemicals on shrimp health (Figure 1).

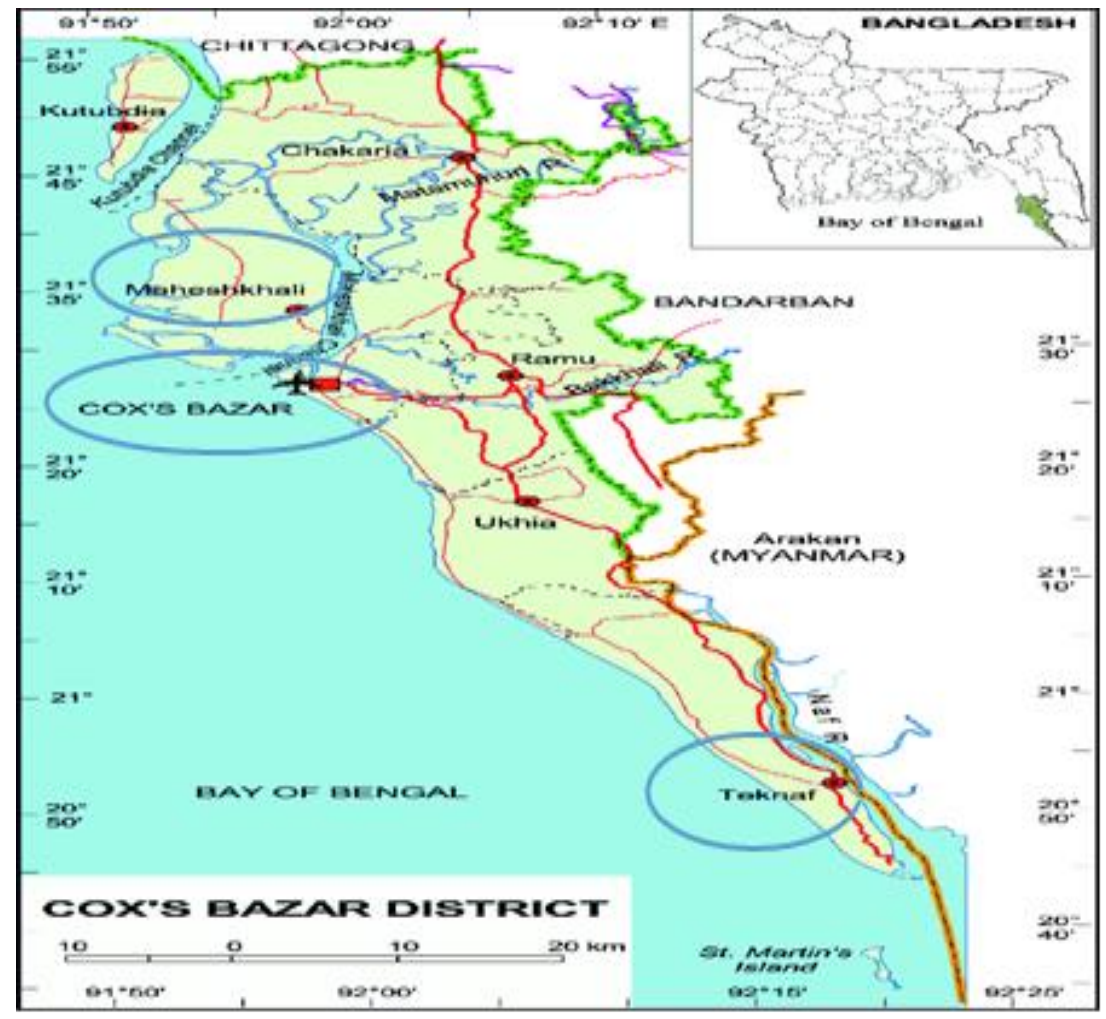

Figure 1. Selected upazilas of the southern coastal region of Bangladesh.

\subsection{Data collection}

Data were collected through questionnaire interview with shrimp farmers considering two farms from each upazila. For questionnaire interview a set of questionnaire was developed composed of open form of questions. A total 36 farmers were personally interviewed including 6 key informants.

\subsection{Record of water quality parameters}

Water quality parameters were recorded with 2 months' interval from shrimp ponds and ghers. Water quality parameters like temperature, dissolved oxygen (DO), $\mathrm{pH}$, ammonia and alkalinity were determined by respective test kits. 
2.4. Sample collection from the three sampling stations (upazilas) for observing the effects of aqua drugs and chemicals on shrimp health

Shrimp samples were collected from ponds and ghres at two month's interval. For clinical signs collected shrimp were examined by naked eye to observe any superficial injury, infection, and other abnormalities at live condition. For histological observation samples were collected from hepatopancreas and muscle of shrimp. Samples were taken by a sharp sterile scalpel and fixed in Davidson fixative (1:10). Then samples were dehydrated, cleared and infiltrated through an Automatic Tissue Processors (Citadel 1000), samples were sectioned by microtome and stained with hematoxylin and eosin stains. The sections were examined under a photomicroscope. Record of hepatopancreas and muscle sections were done farmwise and seasonwise. Comparisons were made according to health status of shrimp.

\section{Results and Discussion}

\subsection{Water quality parameters measurement of the selected shrimp culture ponds}

In any shrimp farming, management of water quality is of primary consideration particularly in ponds with higher stocking rates. Degradation of water quality is detrimental to shrimp growth and survival. The recorded water temperature was ranged between $26^{\circ} \mathrm{C}$ to $32^{\circ} \mathrm{C}$ in summer and $23^{\circ} \mathrm{C}$ to $28^{\circ} \mathrm{C}$ in rainy season (Table 4). The highest temperature was $32^{\circ} \mathrm{C}$ during summer season recorded from Unique Aquaculture of Teknaf and the lowest was $23^{\circ} \mathrm{C}$ from Aquaculture Farm Limited of Cox's Bazar Sadar in rainy season. Hossain (2017) observed that, the highest temperature was $34^{\circ} \mathrm{C}$ recorded during summer from shrimp culture ponds of Dacope upazila. Mazid (1994) stated that both shrimp and prawn production would be better at temperature $25-30^{\circ} \mathrm{C}$ which was slightly lower than the present study. Dissolved oxygen were varied between 4.5 to $6.8 \mathrm{mg} / \mathrm{L}$. The highest dissolved oxygen was $6.8 \mathrm{mg} / \mathrm{L}$ recorded from Unique Aquaculture of Teknaf during summer season and the lowest was $4.5 \mathrm{mg} / \mathrm{L}$ from Rabiul's gher of Maheshkhali during summer. Hossain (2017) observed that highest level of dissolved oxygen (DO) was $6.00 \mathrm{mg} / \mathrm{L}$ during summer season from culture ponds of Botiaghata upazila and the lowest was $3.00 \mathrm{mg} / \mathrm{L}$ observed during winter from culture ponds of Dacope upazila. Zafar (2012) observed that dissolved oxygen ranged from 6 to $13 \mathrm{mg} / \mathrm{L}$ during dry season and 4 to $69 \mathrm{mg} / \mathrm{L}$ during wet season with a mean of $8.5 \mathrm{mg} / \mathrm{L}$ and $6.5 \mathrm{mg} / \mathrm{L}$ in prawn and shrimp farms. DoF (2005) stated that optimum range of dissolved oxygen for shrimp and prawn was $>4 \mathrm{mg} / \mathrm{L}$ which is almost similar of the findings of the present study. $\mathrm{pH}$ values were ranged between 7.00 to 8.00 . The highest $\mathrm{pH}$ was 8.00 recorded from Beximco Shrimp Farm of Cox's Bazar Sadar in summer season and the lowest was 7.0 recorded from the Aquaculture Farm Limited of Cox's Bazar Sadar (Table 4). Hossain (2017) reported that the highest pH value was 7.8 recorded during summer from culture pond of Botiaghat upazila and the lowest $\mathrm{pH}$ was 6.6 recorded during winter from culture pond of Dacope upazila. The ranges of alkalinity were 70 to $130 \mathrm{ppm}$. However, in the study areas the highest alkalinity was 130 ppm recorded from Beximco Shrimp Farm in Cox's Bazar Sadar during summer and the lowest was $70 \mathrm{ppm}$ from the Unique Aquaculture of Cox's Bazar Sadar in rainy season. Ammonia values were ranged between 0.0 to $0.8 \mathrm{mg} / \mathrm{L}$ during the study period. Maximum level of ammonia was $0.8 \mathrm{mg} / \mathrm{L}$ recorded from Beximco Shrimp Farm of Cox's Bazar Sadar during summer season and minimum level of ammonia was $0.1 \mathrm{mg} / \mathrm{L}$ recorded from Unique Aquaculture of Cox's Bazar Sadar in summer season. According to Ahmed et al. (2009) increased value of ammonia and decreased value of temperature and dissolved oxygen (DO) during winter season could lead to an increased prevalence of disease in fish. However, the above value of ammonia was more or less similar with the result of present study and which are suitable for shrimp culture (Table 1). 
Table 1. Seasonal variation of water quality parameters of different sampling areas.

\begin{tabular}{|c|c|c|c|c|c|c|c|}
\hline Study areas & Farms & Seasons & Dissolved oxygen (mg/l) & Temperature $\left({ }^{\circ} \mathrm{C}\right)$ & pH & Ammonia (mg/l) & Alkalinity (ppm) \\
\hline Cox’s Bazar & Beximco & Summer & $5.0 \pm 0.22$ & $30.00 \pm 0.95$ & $8.0 \pm 0.20$ & $0.8 \pm 0.00$ & $130 \pm 0.95$ \\
\hline \multirow[t]{3}{*}{ Sadar } & Shrimp Farm & Rainy & $5.5 \pm 0.10$ & $26.25 \pm 0.55$ & $7.4 \pm 0.15$ & $0.1 \pm 0.00$ & $98 \pm 0.58$ \\
\hline & Aquaculture & Summer & $6.0 \pm 0.43$ & $31.77 \pm 0.43$ & $7.0 \pm 0.23$ & $0.1 \pm 0.00$ & $120 \pm 0.75$ \\
\hline & Farm Limited & Rainy & $6.5 \pm 0.56$ & $23.00 \pm 0.72$ & $7.1 \pm 0.17$ & $0.0 \pm 0.00$ & $116 \pm 0.35$ \\
\hline \multirow[t]{4}{*}{ Teknaf } & Unique & Summer & $6.8 \pm 0.75$ & $32.00 \pm 0.65$ & $7.8 \pm 0.21$ & $0.1 \pm 0.00$ & $125 \pm 0.76$ \\
\hline & Aquaculture & Rainy & $5.0 \pm 0.23$ & $26.00 \pm 0.29$ & $7.3 \pm 0.34$ & $0.0 \pm 0.00$ & $70 \pm 0.25$ \\
\hline & MKA Shrimp & Summer & $5.0 \pm 0.76$ & $31.00 \pm 0.76$ & $7.8 \pm 0.13$ & $0.1 \pm 0.00$ & $118 \pm 0.43$ \\
\hline & Farm & Rainy & $6.0 \pm 0.31$ & $27.00 \pm 0.52$ & $7.1 \pm 0.30$ & $0.7 \pm 0.00$ & $95 \pm 0.79$ \\
\hline \multirow[t]{4}{*}{ Maheshkhali } & Zaman's Gher & Summer & $4.8 \pm 0.65$ & $31.00 \pm 0.78$ & $7.2 \pm 0.12$ & $0.1 \pm 0.00$ & $110 \pm 0.24$ \\
\hline & & Rainy & $5.5 \pm 0.40$ & $27.00 \pm 0.23$ & $7.3 \pm 0.26$ & $0.4 \pm 0.00$ & $71 \pm 0.59$ \\
\hline & Rabiul's Gher & Summer & $4.5 \pm 0.34$ & $31.00 \pm 0.49$ & $7.1 \pm 0.10$ & $0.6 \pm 0.00$ & $105 \pm 0.32$ \\
\hline & & Rainy & $5.0 \pm 0.60$ & $26.00 \pm 0.75$ & $7.5 \pm 0.15$ & $0.3 \pm 0.00$ & $83 \pm 0.89$ \\
\hline
\end{tabular}




\subsection{Pharmaceuticals companies in the study areas}

It was recorded that about 10 pharmaceuticals companies supplied the aqua-drugs, probiotics and chemicals in the study areas. These are ACI Animal Health Ltd., Advanced Agro Tech, Square pharmaceuticals Ltd., FishTech (BD) Ltd., SK+F Bangladesh Ltd., Eon Animal Health Ltd., Reneta Pharmacceuticals Ltd., Navana Animal Health, CP Agro Ltd. and Fish-World Ltd. They provide various types of products such as Aqumin, Bio- care, AQ Grow-G, Bio aqua, Timsen, and Aqua savor, Aqua clean, Oxy life, Gas trap, Aqua mix and ProW (Table 2). During investigation it was observed that, about 10 pharmaceuticals companies supplied the aquadrugs, probiotics and chemicals in the study areas. These are ACI Animal Health Ltd., Advanced Agro Tech, Square pharmaceuticals Ltd., Fishtech (BD) Ltd., SK+F Bangladesh Ltd., Eon Animal Health Ltd., Reneta Pharmacceuticals Ltd., Navana Animal Health, CP Agro Ltd. and Fish-World Ltd. They provide various types of products such as Aqumin, Bio- care, AQ Grow-G, Bio aqua, Timsen, and Aqua savor, Aqua clean, Oxy life, Gas trap and Aqua mix etc. Akter et al. (2010) mentioned that 23 pharmaceuticals were active for producing and marketing of drugs and chemicals in Khulna district. From the research finding Faruk et al. (2008) it was observed that 33 companies either produced or marketed aqua-drugs and chemicals in Mymensingh district.

It was observed that, farmers of study areas used Potassium permanganate $\left(\mathrm{KMnO}_{4}\right)$ and Bleaching for the treatment of WSD but had no recovery. Farmers used Renamox which had an average of $20-25 \%$ recovery on the treatment of bacterial diseases. By use of Ecodoxin Zoothamnium was 80-85\% recovery. Farmers also used Potassium permanganate (KMnO4) for the treatment of Zoothamnium and Surface fouling disease. In Teknaf areas farmers used several types of drugs for the treatment of bacterial and protozoan diseases. There is no treatment of viral diseases such as White spot disease (WSD) and Yellow head disease (WHD), early mortality syndrome (EMS) which cause devastating loss in the Teknaf region farms. Farmers used Lime and Potassium permanganate $(\mathrm{KMnO} 4)$ to reduce this disease. But the farmers of Maheshkhali areas did not used any aquadrugs and chemicals. Faruk et al. (2008) mentioned that chemicals applied by the farmers of Mymensingh region during pond preparation and gas removal. Zeolite, Zeolite plus, JV Zeolite and Geotox had the highest impact on pond preparation as an average of $80-85 \%$. Zeocare, Alpha Zeolite and Green Geolite had an average of 70-75\% positive impacts. Islam (2013) also mentioned that farmers of coastal regions used several chemicals such as Oxy life, Oxy gold, Oxy max, Pure oxy and Oxy dox to increase dissolved oxygen (DO) in ghers. According to Shamsuzzaman and Biswas (2012) chemicals were used by the farmers in coastal regions like Oxy grow, Oxy flow, Quick oxygen, Oxymax, Oxy gold, Oxy-A, Oxy plus, Bio care and Bio ox. Faruk et al. (2008) reported that in Khulna region, Megavit aqua and Cevit vet had the highest positive impact on growth of shrimp and prawn as $75-80 \%$. Whereas, in Cox's Bazar region, the same drugs were observed the highest positive impacts of $75-80 \%$ on growth of shrimp. Hossain (2017) mentioned that Oxolinic acid, Renamycin, Oxytetracycline, Lime, Salt, Formalin and Eco-solution had an average recovery of $75-85 \%$ and $55-70 \%$ from bacterial and fungal diseases of shrimp.

Scientist proposes that better pond management and management during culture period can play salient role in the prevention of most disease. As most of our farmers either not well educated or illiterate, they are not conscious about pond management and culture management as well.

Table 2. Aqua-drugs producing companies and their products recorded from study areas.

\begin{tabular}{|l|l|l|}
\hline SL. No. & Aqua-drugs producing companies & Products \\
\hline 01 & ACI Animal Health Ltd. & Aqumin, Bio- care, AQ grow-G \\
\hline 02 & Advanced Agro Tech Ltd. & Aquazet, Omicide, Aqua-gold \\
\hline 03 & Square Pharmaceuticals Ltd. & Aqua clean, Oxy life, Gas trap and Aqua mix \\
\hline 04 & FishTech (BD) Ltd. & Pro-W \\
\hline 05 & SK+F Bangladesh Ltd. & Well zeolite \\
\hline 06 & Eon Animal Health Ltd. & Bio aqua, Timsen, and Aqua savor \\
\hline 07 & Reneta Pharmacceuticles Ltd. & Renamox and Renamycin \\
\hline 08 & Navana Animal Health Ltd. & Oxy plus and Oxin WS \\
\hline 09 & CP Agro Ltd. & Prols, pH fixer and Super biotic \\
\hline 10 & Fish-World Ltd. & Geo top and Aqua cleaner plus \\
\hline
\end{tabular}

\subsection{Effects of aqua-drug in Cox's Bazar Sadar area}

The farmers of Cox's Bazar Sadar upazila used chemical during pond preparation, growth promotion, bacterial and fungal disease treatment of shrimp. Farmers used Bleaching powder as a disinfectant. The highest recovery was recorded $90-96 \%$ by use of Bleaching powder in Aquaculture Farm limited of Cox's Bazar Sadar area. On the other hand, the lowest recovery was recorded $60-65 \%$ by use of Zeolite plus in Beximco shrimp farm of 
Cox's Bazar Sadar upazila. The average recovery was recorded from Beximco shrimp farm of Cox's Bazar Sadar upazila. By use of Ecodoxin Zoothamnium was 80-85\% recovery (Table 3).

Table 3. Effects of aqua-drugs and chemical in Cox's Bazar Sadar area.

\begin{tabular}{|l|l|l|l|l|}
\hline Category & $\begin{array}{l}\text { Trade names of } \\
\text { Drugs/ Chemicals }\end{array}$ & Dose & Purpose of use & $\begin{array}{l}\text { Effectiveness } \\
(\%)\end{array}$ \\
\hline $\begin{array}{l}\text { Pond preparation } \\
\text { and water quality } \\
\text { management }\end{array}$ & Bio-tuff & $\begin{array}{l}\text { Pond preparation and } \\
\text { culture 15-20 kg and 7- } \\
10 \mathrm{~kg} / \mathrm{acre}\end{array}$ & $\begin{array}{l}\text { Improve soil and water } \\
\text { quality }\end{array}$ & $70-75$ \\
& Lime & $1-1.5 \mathrm{~kg} / \mathrm{dec}$ & $\begin{array}{l}\text { Disinfectant, pH } \\
\text { maintenance }\end{array}$ & $90-95$ \\
\cline { 2 - 5 } & Zeolite Plus & $20-30 \mathrm{~kg} / \mathrm{acre}$ & Remove gas & $60-65$ \\
\hline \multirow{2}{*}{ Oxygen suppliers } & \multicolumn{1}{|c|}{ Oxy plus } & $500 \mathrm{~g} / \mathrm{acre}$ & Instant oxygen supply & $60-70$ \\
\cline { 2 - 5 } & Oxy max & $250-500 \mathrm{~g} / \mathrm{acre}$ & Increase dissolved oxygen & $80-85$ \\
\hline Disinfectants & Bleaching powder & $250-350 \mathrm{~g} / \mathrm{acre}$ & Disinfection & $90-96$ \\
\hline Growth promoters & Aqumin & $200 \mathrm{~g} / 100 \mathrm{~kg}$ feed & Used in vitamin deficiency & $75-80$ \\
\hline Antibiotics & VIUSID & $200-300 \mathrm{~g} / 100 \mathrm{~kg}$ feed & $\begin{array}{l}\text { Inhibit Zoothamnium } \\
\text { infection }\end{array}$ & $60-70$ \\
\hline Probiotics & Ecodoxin & $5 \mathrm{~g} / \mathrm{kg}$ body weight & Inhibit pathogen & $80-85$ \\
\cline { 2 - 5 } & Bluemix & $4-6 \mathrm{~L} / \mathrm{acre}$ & Improve soil quality & $80-85$ \\
\hline
\end{tabular}

\subsection{Effects of aqua-drugs in Teknaf area}

During field investigation, in Teknaf areas farmer used several types of drugs for the treatment of bacterial and protozoan diseases. Such as Geotox to remove gas, TSP to proliferation of algae and Zymetin to inhibit growth of pathogens. Farmers used more aqua-drugs in rainy season than summer. By use of Oxyflow instant oxygen supply was recorded $75-80 \%$ recovery. The highest recovery was recorded $90-95 \%$ by use of Lime in Unique Aquaculture of Teknaf. On the other hand, the lowest recovery was recorded $60-65 \%$ by use of Renamox in MKA shrimp farm of Teknaf upazila. The average recovery was recorded Unique Aquaculture of Teknaf upazila (Table 4).

Table 4. Effects of aqua-drugs and chemical in Teknaf area.

\begin{tabular}{|l|l|l|l|l|}
\hline Category & $\begin{array}{l}\text { Trade names of } \\
\text { Drugs/ Chemicals }\end{array}$ & Dose & Purpose of use & Effectiveness (\%) \\
\hline \multirow{2}{*}{$\begin{array}{l}\text { Pond preparation } \\
\text { and water quality } \\
\text { management }\end{array}$} & Geotox & $20-25 \mathrm{~kg} / 100 \mathrm{dec}$ & Remove gas & $80-85$ \\
\cline { 2 - 5 } & TSP & $100-150 \mathrm{~g} / \mathrm{dec}$ & Proliferation of algae & $85-90$ \\
\cline { 2 - 5 } & Lime & $1-1.5 \mathrm{~kg} / \mathrm{dec}$ & $\begin{array}{l}\text { Disinfectant, } \\
\text { maintain }\end{array}$ & $90-95$ \\
\hline Oxygen suppliers & Oxyflow & $250-350 \mathrm{~g} / \mathrm{acre}$ & Oxygen supplement & $75-80$ \\
\hline Disinfectants & Timsen & $\begin{array}{l}20 \mathrm{~g} / 33 \mathrm{dec} \\
\text { (per bigha) }\end{array}$ & Kill microbes & $90-92$ \\
\hline Growth promoters & Aqua boost & $500 \mathrm{~g} / \mathrm{Metric}$ ton feed & $\begin{array}{l}\text { Increase organic acid in } \\
\text { feed }\end{array}$ & $75-85$ \\
\hline Antibiotics & Renamox & $30 \mathrm{~g} / 100 \mathrm{~kg}$ feed & Increase resistance & $60-65$ \\
\hline Probiotics & Zymetin & $5 \mathrm{~g} / \mathrm{kg}$ feed & $\begin{array}{l}\text { Inhibit growth of } \\
\text { pathogens }\end{array}$ & $80-90$ \\
\hline
\end{tabular}

\subsection{Effects of aqua-drugs in Maheshkhali area}

From investigation, it was observed that farmer's at Maheshkhali upazila do not use several types of aqua drugs and chemicals for the treatment of bacterial and protozoan diseases. They only used cow dung to proliferation of algae and banana leaf to remove turbidity of water. They cultured the shrimp in gher, they do not use any aquadrugs and chemicals in this system. Because it is very cost effective.

\subsection{Aqua-drugs against diseases and percentage in the study areas}

The highest recovery was recorded $40-55 \%$ by use of Lime and Renamycin in case of Surface fouling disease in Beximco shrimp farm of Cox's Bazar Sadar area. On the other hand, the lowest recovery was recorded 5-10\% by use of Lime and $\mathrm{KMnO}_{4}$ in case of EMS in MKA shrimp farm of Teknaf and Aquaculture Farm Limited of 
Cox's Bazar Sadar upazila. No recovery was found in case of White spot disease (WSD) in both the shrimp farm of Teknaf and Cox's Bazar Sadar upazila. Various categories of investigated aqua-drugs with their purpose of uses, doses and recovery percentages are mentioned in (Table 5).

Table 5. Various categories of investigated aqua-drugs with their purpose of uses, doses and disease recovery percentages in the study areas.

\begin{tabular}{|c|c|c|c|c|}
\hline $\begin{array}{l}\text { Study } \\
\text { area }\end{array}$ & Disease name & Disease Symptoms & Drug and dose & $\begin{array}{l}\text { Recovery } \\
(\%)\end{array}$ \\
\hline \multirow{4}{*}{$\begin{array}{l}\text { Cox's } \\
\text { Bazar } \\
\text { Sadar }\end{array}$} & $\begin{array}{l}\text { White spot disease } \\
\text { (WSD) }\end{array}$ & $\begin{array}{l}\text { White spot on the inside of the } \\
\text { shell and carapace }\end{array}$ & $\begin{array}{l}\text { Malachite green } 10 \mathrm{~g} / \mathrm{dec} \\
\text { Bleaching powder } 60 \mathrm{ppm}\end{array}$ & No recovery \\
\hline & $\begin{array}{l}\text { Early mortality } \\
\text { syndrome (EMS) }\end{array}$ & $\begin{array}{l}\text { Reddish discoloration of juvenile } \\
\text { shrimp, black spot and chronic } \\
\text { soft shelling }\end{array}$ & $\begin{array}{l}\text { Lime } 0.5-1 \mathrm{~kg} / \text { feed. } \\
\mathrm{KMnO}_{4} 0.1-0.2 \mathrm{ppm}\end{array}$ & $5-10$ \\
\hline & $\begin{array}{l}\text { Yellow head disease } \\
\text { (YHD) }\end{array}$ & $\begin{array}{l}\text { Pale bodies, swollen } \\
\text { cephalothorax and Yellowish } \\
\text { hepatopancreas }\end{array}$ & $\begin{array}{l}\text { Eco solution 0.1-0.2 ppm. } \\
\text { Basudin } 150 \mathrm{~g} / 33 \mathrm{dec}\end{array}$ & $15-20$ \\
\hline & $\begin{array}{l}\text { Surface fouling } \\
\text { disease }\end{array}$ & $\begin{array}{l}\text { Infected shrimps show black/ } \\
\text { brown gills or appendages } \\
\text { discoloration }\end{array}$ & $\begin{array}{l}\text { Renamycin } 5 \mathrm{~g} / \mathrm{kg} \text { feed. } \\
\text { Lime } 0.5-1 \mathrm{~kg} / \mathrm{dec}\end{array}$ & $40-50$ \\
\hline \multirow{3}{*}{$\begin{array}{l}\text { Teknaf } \\
\text { Upazila }\end{array}$} & $\begin{array}{l}\text { Yellow head disease } \\
\text { (YHD) }\end{array}$ & $\begin{array}{l}\text { Pale bodies, and Yellowish } \\
\text { hepatopancreas }\end{array}$ & $\begin{array}{l}\text { Eco solution } 0.1-0.2 \mathrm{ppm} . \\
\text { Basudin } 150 \mathrm{~g} / 33 \mathrm{dec}\end{array}$ & $15-20$ \\
\hline & $\begin{array}{l}\text { White spot disease } \\
\text { (WSD) }\end{array}$ & $\begin{array}{l}\text { White spot on the inside of the } \\
\text { shell and carapace }\end{array}$ & $\begin{array}{l}\text { Malachite green } 10 \mathrm{~g} / \mathrm{dec} \\
\text { Bleaching powder } 60 \mathrm{ppm}\end{array}$ & No recovery \\
\hline & $\begin{array}{l}\text { Early mortality } \\
\text { syndrome (EMS) }\end{array}$ & $\begin{array}{l}\text { Reddish discoloration of juvenile } \\
\text { shrimp, black spot and chronic } \\
\text { soft shelling }\end{array}$ & $\begin{array}{l}\text { Lime } 0.5-1 \mathrm{~kg} / \mathrm{feed} . \\
\mathrm{KMnO}_{4} 0.1-0.2 \mathrm{ppm}\end{array}$ & $5-10$ \\
\hline
\end{tabular}

\subsection{Production of shrimp in study areas}

Shrimp production were ranged from $1050 \mathrm{~kg} / \mathrm{ha}$ to $11795 \mathrm{~kg} / \mathrm{ha}$ in the study areas. The highest production was recorded from Aquaculture Farm Limited at Cox's Bazar Sadar and the lowest was from Zaman's gher at Maheshkhali upazila. Production in summer were more than rainy season. In shrimp ponds was higher production than ghers (Table 6).

Table 6. Shrimp production in the study areas.

\begin{tabular}{|l|l|l|}
\hline Study area & Farm name & Production of shrimp (kg/ ha) from one crop \\
\hline \multirow{2}{*}{ Maheshkhali } & Zaman's Gher & 1050 \\
\cline { 2 - 3 } & Rabiul's Gher & 1235 \\
\hline \multirow{2}{*}{ Cox's Bazar Sadar } & Beximco Shrimp Farm & 9075 \\
\cline { 2 - 3 } & Aquaculture Farm Limited & 11795 \\
\hline \multirow{2}{*}{ Teknaf } & Unique Aquaculture & 10886 \\
\cline { 2 - 3 } & MKA Shrimp Farm & 9980 \\
\hline
\end{tabular}

\section{Conclusions}

Shrimp is known as 'white gold' for its valuable demand and intrinsic quality for export. Culture of shrimp is very sensitive and mostly its affected by different types of microbes and pathogens and causes illness to ultimate death. For safe shrimp production intensive/ semi intensive methods needs a lot of aqua drugs and chemicals than shrimp production in ghers. Whereas aqua drugs and chemicals plays crucial role to prevent and control the disease causing agents and hence boost the shrimp production. Shrimp production were recorded from 1050 $\mathrm{kg} / \mathrm{ha}$ to $11795 \mathrm{~kg} / \mathrm{ha}$ in the study areas. The highest production was recorded from Aquaculture Farm Limited at Cox's Bazar Sadar and the lowest was from Zaman's gher at Maheshkhali upazila. Production in summer were more than rainy season and shrimp ponds was higher production than ghers.

\section{Acknowledgements}

The author would like to extend gratitude to the co-authors for their kind assistance and co-operation for data collection \& histopathological analysis in the laboratory which contributed to the accomplishment of this 
experiment. The author also thankful to the Department of Aquaculture, Bangladesh Agricultural University for providing laboratory facilities and all support to fulfill the research work.

\section{Conflict of interest}

None to declare.

\section{References}

Ahmed GU, AMO Faruque, MR Hasan and MA Hossain, 2014. Disease problems in shrimp sector in Khulna district of Bangladesh: A question of sustainability. J. of Ind. Fish. Assoc., 13: 121-129.

Ahmed GU, NM Hossain and MM Hasan, 2009. Seasonal variation of disease and pathology of perch, Nandus nandus (Hamilton) from Oxbow Lake fisheries of Bangladesh. Eco. frien. Agri. J., 2: 761-768.

Akter MM, MSR Khan, SM Galib, MDG Nahar and MR Haque, 2010. Comparison of plankton communities among freshwater prawn post larvae rearing ponds. Int. J. of Bio Resc., 1: 21-26.

Alam A, 2014. Use of aqua-medicine and chemicals in aquaculture in Shatkhira district. MS Thesis, Department of Aquaculture, Bangladesh Agricultural University, Mymensingh, Bangladesh.

Apud FD, A Eleonor, DC Tendencia and V Johan, 1989. White spot syndrome virus (WSSV) risk factors associated with shrimp farming practices in polyculture and monoculture farms in the Philippines. Aq. Elsev. J., 311: 87-93.

Boyd CE, 1976. Grow-out systems water quality and soil management. Freshwater prawn culture: the farming of Macrobrachium rosenbergii. Blac. Sci., 18: 221-238.

DoF, 2005. Fish Fortnight 2005 (leaflet), Dhaka.

DoF, 2019. National Fish Week 2019 Compendium (in Bengali). Department of Fisheries, Ministry of Fisheries and Livestock, Dhaka, Bangladesh. pp. 145.

Faruk MAR, MM Ali and ZP Patwary, 2008. Evaluation of the status of use of chemicals and antibiotics in freshwater aquaculture activities with special emphasis to fish health management. J. of Bang. Agric. Univ., 6: 381-390.

Hossain MJ, 2017. Effects of aqua-drugs and chemicals on shrimp health and production in Khulna region. MS Thesis, Department of Aquaculture, Bangladesh Agricultural University, Mymensingh, Bangladesh.

Islam KR, 2013. Study on impact of aqua-drugs and chemicals on shrimp health and production in Bangladesh. MS Thesis, Department of Aquaculture, Bangladesh Agricultural University, Mymensingh, Bangladesh.

Uddin MA, GU Ahmed, MNAS Aktar and MU Ahmad, 2019. Health status of cultured shrimp (Penaeus monodon) in Cox's Bazar region. Bangladesh J. Fish., 31: 295-303.

Mazid MA, 1994. An overview of the social and economic impact and management of fish and shrimp disease in Bangladesh, with an emphasis on small-scale aquaculture. Primary aquatic animal health care in rural, small scale aquaculture development. FAO Fisheries Technical paper. 406: 21-25.

Shamsuzzaman MM and TK Biswas, 2012. Aqua chemicals in shrimp farm: A study from south west coast of Bangladesh. Egypt. J. of Aq. Resc., 38: 275-285.

Zafar MA, 2012. Impacts of shrimp and prawn farming on water and soil quality parameters in southwest Bangladesh. MS Thesis, Department of Fisheries Management, Bangladesh Agricultural University, Mymensingh, Bangladesh. 